\section{Mam and Sam}

\author{
Douglas Palmer
}

Mammoth. By Adrian Lister and Paul Bahn. Macmillan Inc., USA: 1994. Pp. 168. $\$ 30$.

Seismosaurus: The Earth Shaker. By David G. Gillette. Columbia University Press: 1994. Pp. 205. \$39.95, £26.50.

'MАммотн' is still a remarkably and perhaps peculiarly common word that continues to be used to epitomize immensity despite our general knowledge of much larger animals (blue whales, sauropod dinosaurs such as Seismosaurus).

But it is perhaps no accident that we have this linguistic association, given our past material and imaginative connection with mammoths and the other members of the Ice Age megafauna. As this book so clearly illustrates and describes, for more than 200,000 years these shaggy elephants were a dominant species in the Northern Hemisphere, with herds constantly on the move, grazing their way back and forth with the seasons. And, like the vast herds of buffalo that roamed the Great Plains of North America, they seem to have been too much of a temptation for human hunters to resist.

From boomerangs (see Nature 329, $436 ; 1987)$ to building blocks, clothes to fuel, the bits and pieces of mammoths have been put to use by human hunters, their form evoked on cave walls and in sculpture; but whether or not our ancestors finally wiped them out is still a moot point. As has been recently discovered (Nature 362, 337; 1993), mammoths survived on the Arctic island of Wrangel until as recently as 4,000 years ago, becoming dwarfed in the process. As the authors show, their extinction is a complex issue. Read the book and decide for yourself.

Like the best of semipopular books, this is an excellent example of the soft approach to serious science: it is accurate and up to date (the Wrangel and other 1993 information is included) and written by acknowledged international experts in the field. Buy it to encourage a youngster but read it yourself first - mammoths can

\section{IMAGE UNAVAILABLE FOR COPYRIGHT REASONS}

A baby mammoth from Siberia.

\section{IMAGE UNAVAILABLE FOR COPYRIGHT REASONS}

Long views of the past - from left to right, Seismosaurus, Ultrasaurus and Supersaurus. Monochrome painting by John Sibbick, 1992.

still engage an adult's imagination.

The most frustrating thing about these remarkable beasts is that we have missed them by only some 4,000 years. There is a lesson here for our treatment of the remaining megafauna: it would seem that apparently isolated populations of a few thousand are not enough for the survival of a species.

We have had Supersaurus and Ultrasaurus, but even in the media-driven world of dinosaur superlatives, Seismosaurus (Earth-shaker lizard) must be near the apogee in general largesse at between 128 and 170 feet in length and about 100 tonnes in weight.

Fortunately, Gillette avoids the temptation to indulge in the near-hysteria so often fostered by 'dinohype' and tells an interesting and straightforward tale of his excavation of this remarkable sauropod and its taphonomy (study of burial processes).

Originally found in 1979 by some hikers in the mesalands of New Mexico near Albuquerque, Seismosaurus is by far the longest dinosaur known. The story has taken the intervening 15 years to mature. Considering the potential of such an interesting find to generate rancour and skulduggery between vested interests, it is heartening to find the unfolding story to be one of remarkable luck, persistence, cooperation and painstaking work by a lot of people, both professionals and amateurs in the true sense.

Luckily the finders included a geologist, Jan Cummings, who had a good idea of what had been found, a few unusually large and still connected vertebrae of a sauropod dinosaur in the late Jurassic sandstones of the Morrison formation. He was able to convince Gillette, then curator of the New Mexico Museum of Natural History in Albuquerque, to have a look. Luckily again, Gillette was able to engage the interest and expertise of a whole range of scientists from the Los Alamos, Oak Ridge and Sandia National Laboratories. They were able to bring enormous enthusiasm for problem-solving and to gain access to high-tech equipment for finding more of 'Sam', the seismic sauropod.

Hydroxyapatite, the mineral component of bone, fluoresces, so they tried hunting at night with ultraviolet light; fossil bone seems to concentrate uranium minerals, so they tried high-resolution gamma-ray detectors; then there was was ground-penetrating radar, proton magnetometry and acoustic-diffraction tomography, all of which were partially successful in predicting where more bone material might be buried. But it still required traditional excavation techniques to recover what remained in the rock. All these techniques are simply and effectively explained for the novice and the book is an excellent and salutary stimulus for dinosaur enthusiasts of any age.

Finally, the original population of this dinosaur must have been in the order of thousands, with the species surviving for a million years or so. The total number of potential fossil skeletons, each with several very large and heavy bones, must therefore be in the order of millions. And yet we have only one partial skeleton, without the large limb bones. Does this tells us something important about the vagaries of the fossilization process and loss of information about past life? Just how good is the sample? There is nothing novel about these questions but they do emphasize the importance of such remarkable and apparently 'one-off' finds well beyond their statistical insignificance. That these discoveries can be made by anyone with a 'good eye' and a bit of luck gives them a lure that helps to keep palaeontology going.

Douglas Palmer is at 31 Mawson Road, Cambridge CB1 2DZ, UK. 